\title{
Recombinant beta interferon could clear the low-dose infected porcine reproductive and respiratory syndrome virus (PRRSV) in MARC-145 cells
}

\author{
X. SHI ${ }^{1,3^{*}}$, X. ZHANG ${ }^{1 *}$, L. WANG ${ }^{3}$, W. LI I $^{1}$, B. JIANG ${ }^{4}$, R. DENG ${ }^{3}$, A. WANG ${ }^{5}$, G. ZHANG ${ }^{2,3^{*}}$
}

\begin{abstract}
${ }^{1}$ College of life science, Henan Normal University, Xinxiang, Henan 453000, China; ${ }^{2}$ College of Veterinary Medicine and Animal Science, Henan Agricultural University, Zhengzhou, Henan 450002, P. R. China; ${ }^{3}$ Key Laboratory of Animal Immunology of the Ministry of Agriculture, Henan Provincial Key Laboratory of Animal Immunology, Henan Academy of Agricultural Sciences, Zhengzhou, Henan 450002, P. R. China; ${ }^{4}$ Office of Science \& Technology, Chongqing Police College, Chongqing 401331, P. R. China; ${ }^{5}$ Department of Bioengineering, Zhengzhou University, Zhengzhou 450000, P. R. China
\end{abstract}

Received October 23, 2015; revised December 28, 2015; accepted July 28, 2016

\begin{abstract}
Summary. - Porcine reproductive and respiratory syndrome virus (PRRSV) causes one of the most economically devastating and pandemic porcine diseases. Previous study has shown that MARC-145 cells pretreated with recombinant IFN- $\beta$ (rIFN- $\beta$ ) couldn't develop cytopathic effect (CPE) of PRRSV. However, up to date, it is not clear whether MARC-145 cells post-treated with rIFN- $\beta$ could develop CPE of PRRSV. The present work showed that the MARC-145 cells didn't develop the CPE at $120 \mathrm{hr}$ post-infection (p.i.) with low-dose of PRRSV when the cells were pre-treated with rIFN- $\beta$ (Group 1), post-treated with rIFN- $\beta$ at 4 hr p.i. (Group 2), or post-treated with rIFN- $\beta$ at 8 hr p.i. (Group 3), while the MARC-145 cells could develop CPE when the cells were infected with high-dose PRRSV and then treated with rIFN- $\beta$ at 24 hr p.i.. Furthermore, the indirect immunofluorescence assay confirmed that there were a few $\mathrm{N}$ protein-positive cells in the high-dose infected cells in Group 1, Group 2 and Group 3, while there were no N protein-positive cells in the low-dose infected cells in all rIFN- $\beta$ treatment groups. In addition, the numbers of $\mathrm{N}$ protein-positive cells in high-dose infected cells $(\mathrm{MOI}=10)$ in Group 1 were lower than that in Group 2 and Group 3. The results above demonstrated that both pre-treatment with rIFN- $\beta$ and an earlier post-treatment with rIFN- $\beta$ could inhibit the PRRSV replication and could clear the low-dose infected PRRSV, which indicated that the rIFN- $\beta$ had efficient antiviral activities when the cells have been infected with PRRSV.
\end{abstract}

Keywords: PRRSV; recombinant IFN- $\beta$

\section{Introduction}

PRRSV, a positive-stranded RNA virus, is a member of the family Arteriviridae (Meulenberg, 2000). PRRSV has caused one of the most economically important diseases of swine, which is characterized by severe reproductive failure

*Corresponding authors: zhanggaiping2003@163.com, shixibao@ aliyun.com; phone: +86-371-6355-0369."Both authors contributed equally to this work.

Abbreviations: $\mathrm{CPE}=$ cytopathic effect; IFN- $\alpha / \beta=$ Type $\alpha / \beta$ interferons; $\mathrm{MOI}=$ multiplicities of infection; $\mathrm{PRRSV}=$ porcine reproductive and respiratory syndrome virus; p.i. = post-infection; rIFN- $\beta=$ recombinant IFN $-\beta$; TCID $_{50}=50 \%$ tissue culture infected dose in sows and respiratory distress in piglets and growing pigs (Rossow, 1998). Infection with PRRSV also predisposes pigs to secondary infection by bacterial and viral pathogens, which may be due to the immunosuppression induced by the virus (Mateu and Diaz, 2008).

Type $\alpha / \beta$ interferons (IFN- $\alpha / \beta)$ are the first responders against the infection with animal virus (Weber et al., 2004). When virus infects cells, it is recognized by the patternrecognition receptors and finally induces IFN- $\alpha / \beta$ transcription (Bowie and Unterholzner, 2008). Then, IFN- $\alpha$ or IFN- $\beta$ induces the IFN-regulated genes responsible for the antiviral response (Sadler and Williams, 2008), and, finally, the virus infection is cleared. Type I interferons also play a role in adaptive immune response (Le Bon and Tough, 2002). 
Previous study has shown that MARC-145 cells pretreated with recombinant IFN- $\beta$ (rIFN- $\beta$ ) didn't develop CPE of PRRSV (Overend et al., 2007), however, it's not clear whether post-treatment with rIFN- $\beta$ could also control the virus in vitro, which could mimic the clinical trials for the prevention and treatment of the virus. So the purpose of this work was to explore whether the MARC-145 cells could develop the CPE of PRRSV when the MARC-145 cells were pre-treated with rIFN- $\beta$ and then infected with different doses of PRRSV, and also explore whether the MARC-145 cells developed the CPE of PRRSV when infected with different doses of PRRSV and then treated with rIFN- $\beta$ at different times p.i.

\section{Materials and Methods}

Cells and Virus. MARC-145 cells, a fetal green monkey fibroblast cell line derived from MA-104 (Kim et al., 1993), was maintained in Dulbecco's Modified Eagle medium (Gibco) supplemented with $10 \%$ fetal bovine serum (Hyclone). PRRSV strain BJ-4 was a kind gift from Dr. Hanchun Yang (China Agricultural University).

Antiviral recombinant human IFN- $\beta$ Assay. MARC- 145 cells were divided into five groups (see details in Fig. 1) and were grown in 96-well plates overnight. Only the cells in Group 1 were pretreated with the rIFN- $\beta$ (1000 unit/ml) (Peprotech, USA). Twenty-four hours later, the cells in Group 1, Group 2, Group 3 and Group 4 were infected with PRRSV at different multiplicities of infection (MOI), while the negative control cells were mock infected. At 4 hr p.i., the cells in Group 2 were treated with rIFN- $\beta$ (1000 unit/ $\mathrm{ml}$ ), while at $8 \mathrm{hr}$ p.i., the cells in Group 3 were treated with rIFN- $\beta$ (1000 unit/ml), and at $24 \mathrm{hr}$ p.i., the cells in Group 4 were treated with $\mathrm{rIFN}-\beta$ (1000 unit/ml). For detection of CPE, the cells were incubated until $120 \mathrm{hr}$ p.i. and the virus titers were measured by $50 \%$ tissue culture infected dose (TCID50) using the Reed-Muench method. For indirect immunofluorescence assay, the selected infected cells were fixed with methanol for $20 \mathrm{~min}$. Then the cells were incubated overnight at $4^{\circ} \mathrm{C}$ with the monoclonal antibody specific for nucleocapsid (N) protein of PRRSV (VMRD, 2D6), and finally incubated with the FITC-conjugated sheep anti-mouse IgG antibodies (Sigma) for $1 \mathrm{hr}$, after which the cells were counted using a fluorescence microscope.

Cell viability assay. MARC-145 cells were grown in 96-well plates overnight, then the cells were divided into three groups and incubated with rIFN- $\beta$ (1000 unit/ml) for $20 \mathrm{hr}, 44 \mathrm{hr}$ and 92 hr, respectively. MTT (3-(4,5-dimethythiazol-2-yl)-2,5-diphenyl tetrazolium bromide) $5 \mathrm{mg} / \mathrm{ml}$ was added to cells in each well (Sigma) for $4 \mathrm{hr}$. The medium was then removed, the cells were solubilized with $100 \mu \mathrm{l} /$ well dimetyl sulfoxide, and the plate was read in enzyme-linked immunosorbent microplate reader (Bio-Rad 2550, USA) at $490 \mathrm{~nm}$.

Statistical analysis. Statistical analysis was performed using Student's t-test, and the comparisons were considered as statistical significance when $\mathrm{P}<0.05$.

\section{Results}

Both pre-treatment with rIFN- $\beta$ and earlier post-treatment with rIFN- $\beta$ could clear low-dose infected PRRSV

To investigate the effect of pre-treatment and post-treatment with recombinant human IFN- $\beta$ on the replication of PRRSV, MARC-145 cells were divided into five groups (see details in Fig. 1) and were grown in 96-well plates overnight, when only the cells in Group 1 were pretreated with the rIFN- $\beta$ (1000 unit/ml), and $24 \mathrm{hr}$ later, the cells in Group 1, Group 2, Group 3 and Group 4 were infected with PRRSV at the different MOI, while the negative control cells were mock infected. At 4 hr p.i., the cells in Group 2 were treated with rIFN- $\beta$ (1000 unit $/ \mathrm{ml})$, while at $8 \mathrm{hr}$ p.i., the cells in Group 3 were treated with rIFN- $\beta$ (1000 unit/ml), and at $24 \mathrm{hr}$ p.i., the cells in Group 4 were treated with rIFN- $\beta$ (1000 unit/ $\mathrm{ml})$. The results in Table 1 show that the cells in Group 1, Group 2 and Group 3 didn't develop the CPE after $120 \mathrm{hr}$ p.i. Only the cells following high-dose infection (Group 4) developed CPE, while the cells infected with PRRSV at MOI between $10^{-5}$ to 10 in Control group could develop CPE. The virus titers, which were measured by TCID $_{50}$, showed similar results to those in Table 1 (Fig. 2f), that is, both pre-treatment with rIFN- $\beta$ and earlier post-treatment with rIFN- $\beta$ inhibited PRRSV replication.

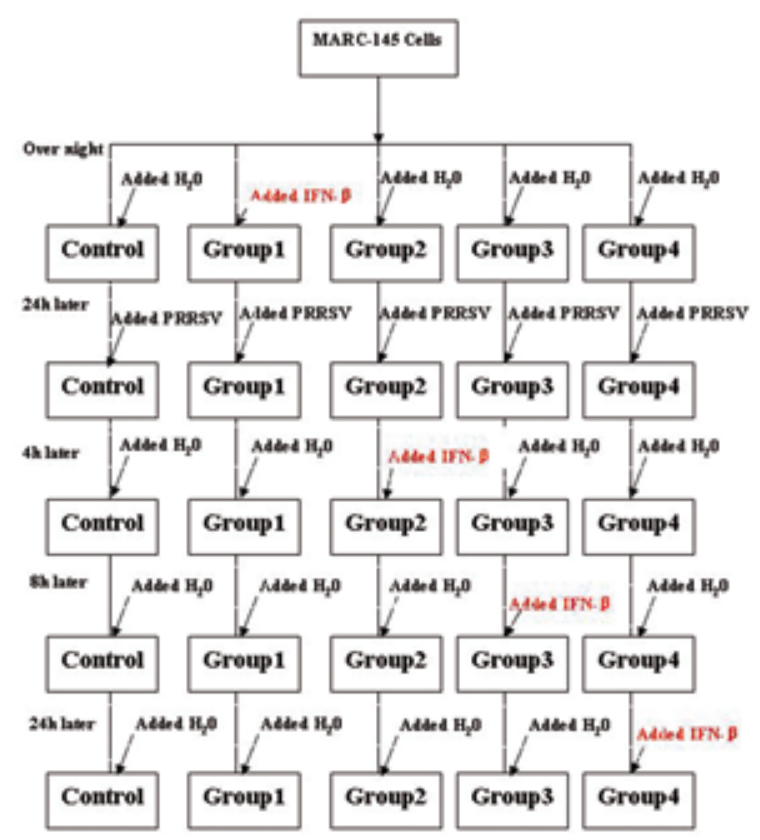

Fig. 1

Design of the antiviral human recombinant IFN- $\beta$ assay The rIFN- $\beta$ was dissolved by Double-distilled water $\left(\mathrm{H}_{2} \mathrm{O}\right)$, so the equal volume of $\mathrm{H}_{2} \mathrm{O}$ was added for control. 
Table 1. MARC-145 pre- and post-treated with rIFN- $\beta$ did not develop CPE in Group 1, Group 2 and Group 3

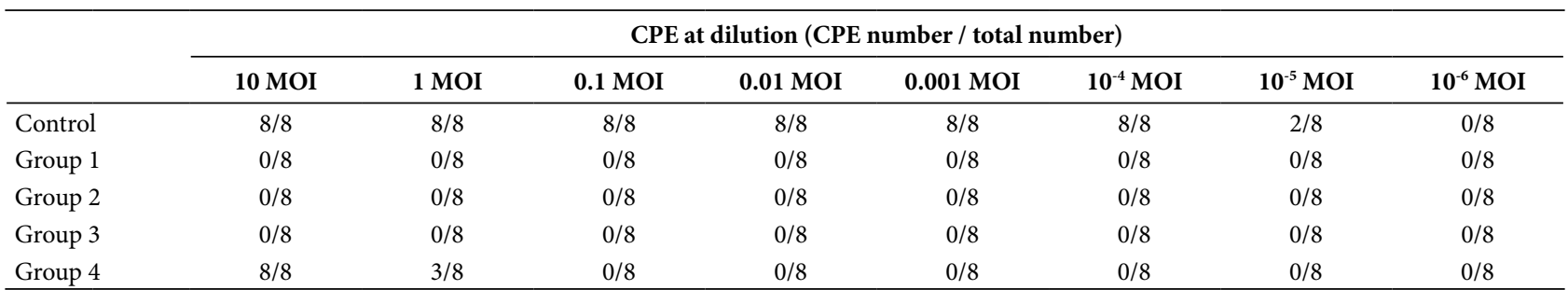

(a)
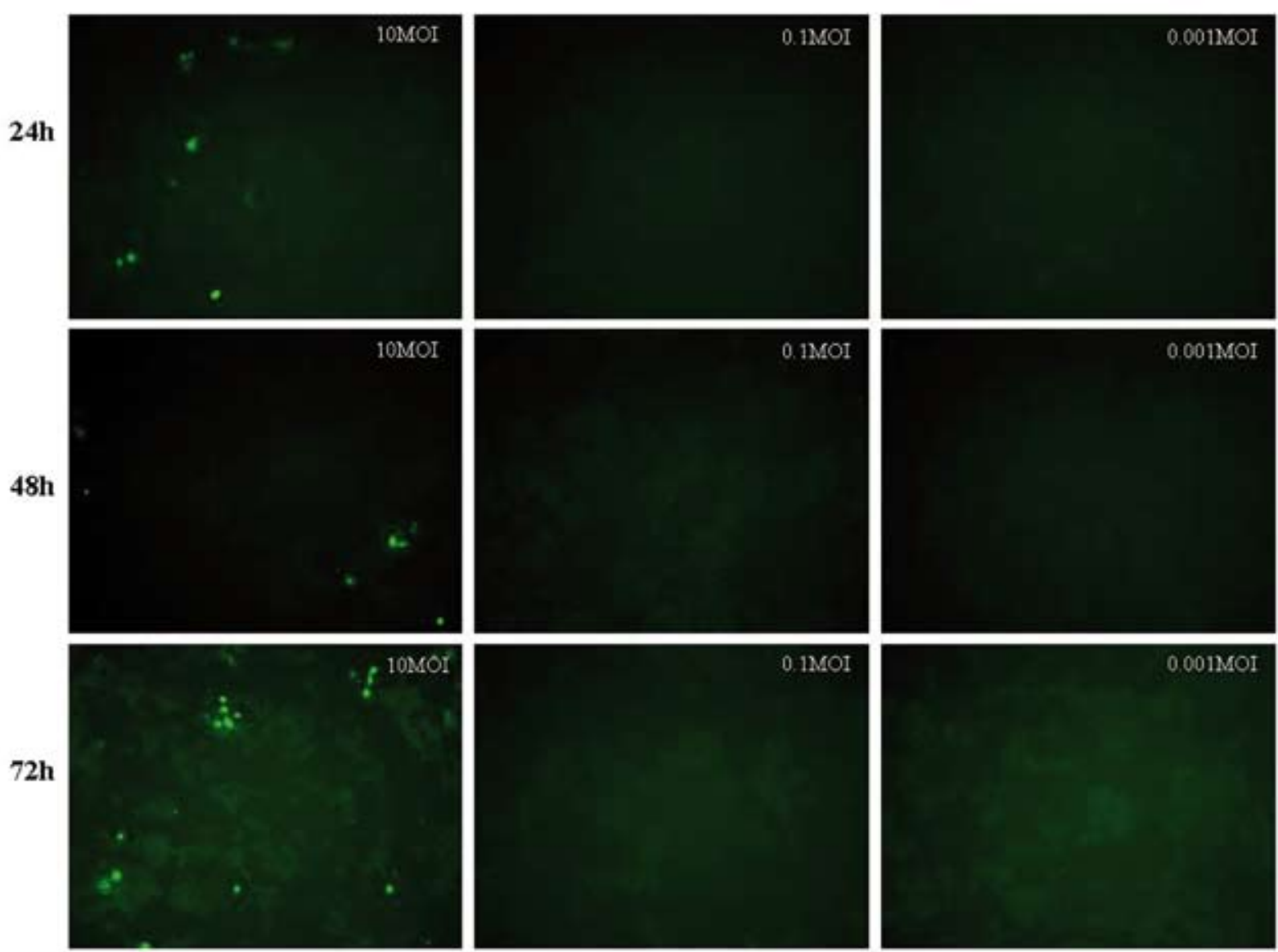

$72 \mathrm{~h}$

(b)
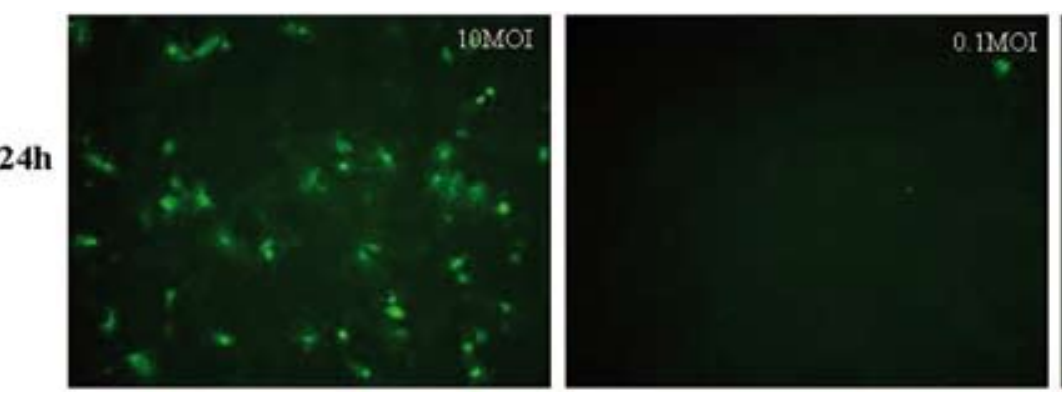

Fig. 2a, b

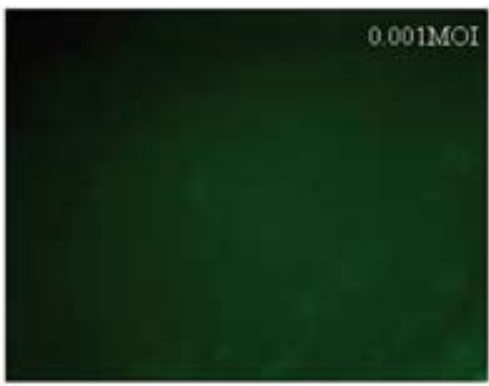



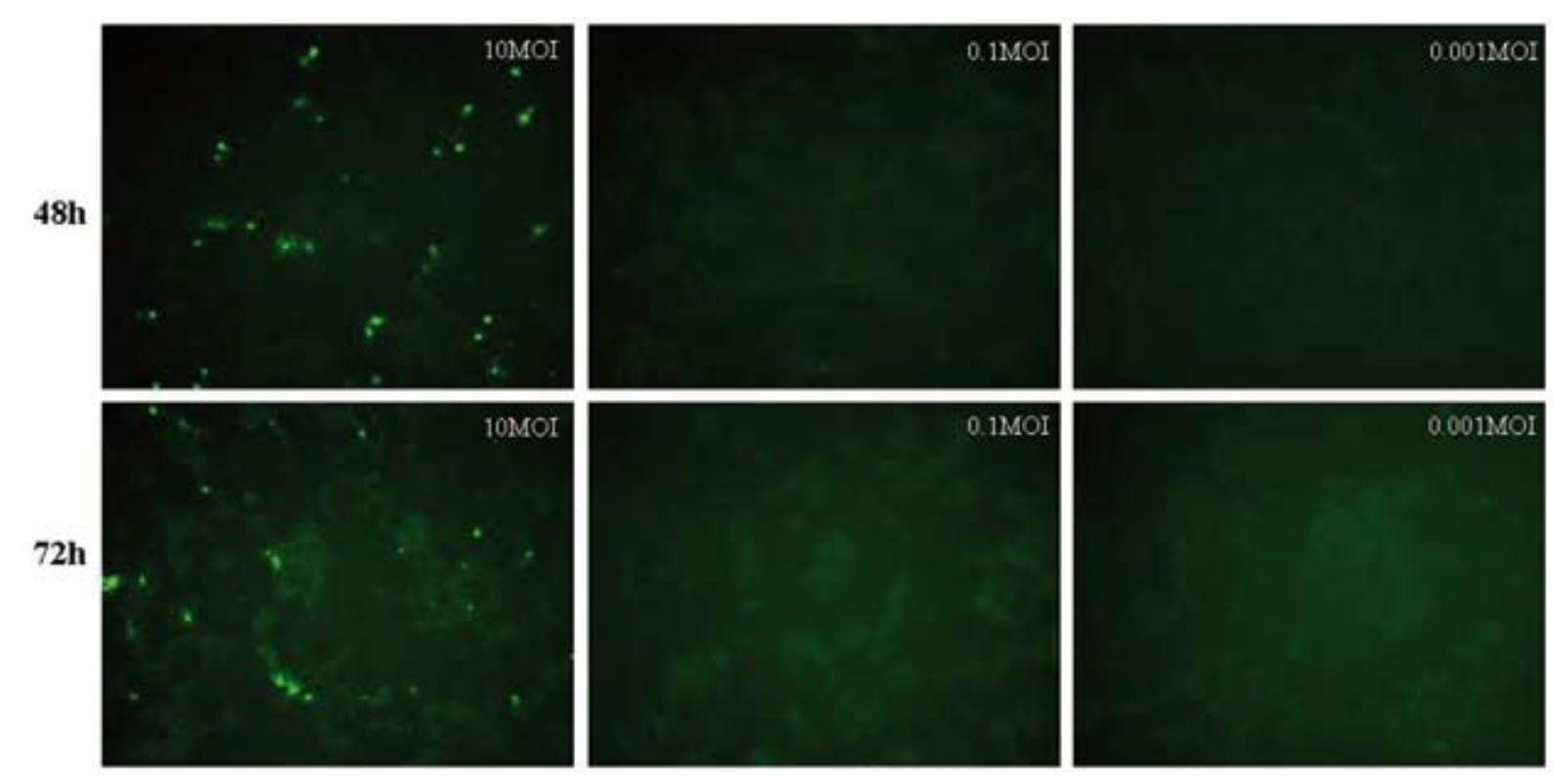

(c)
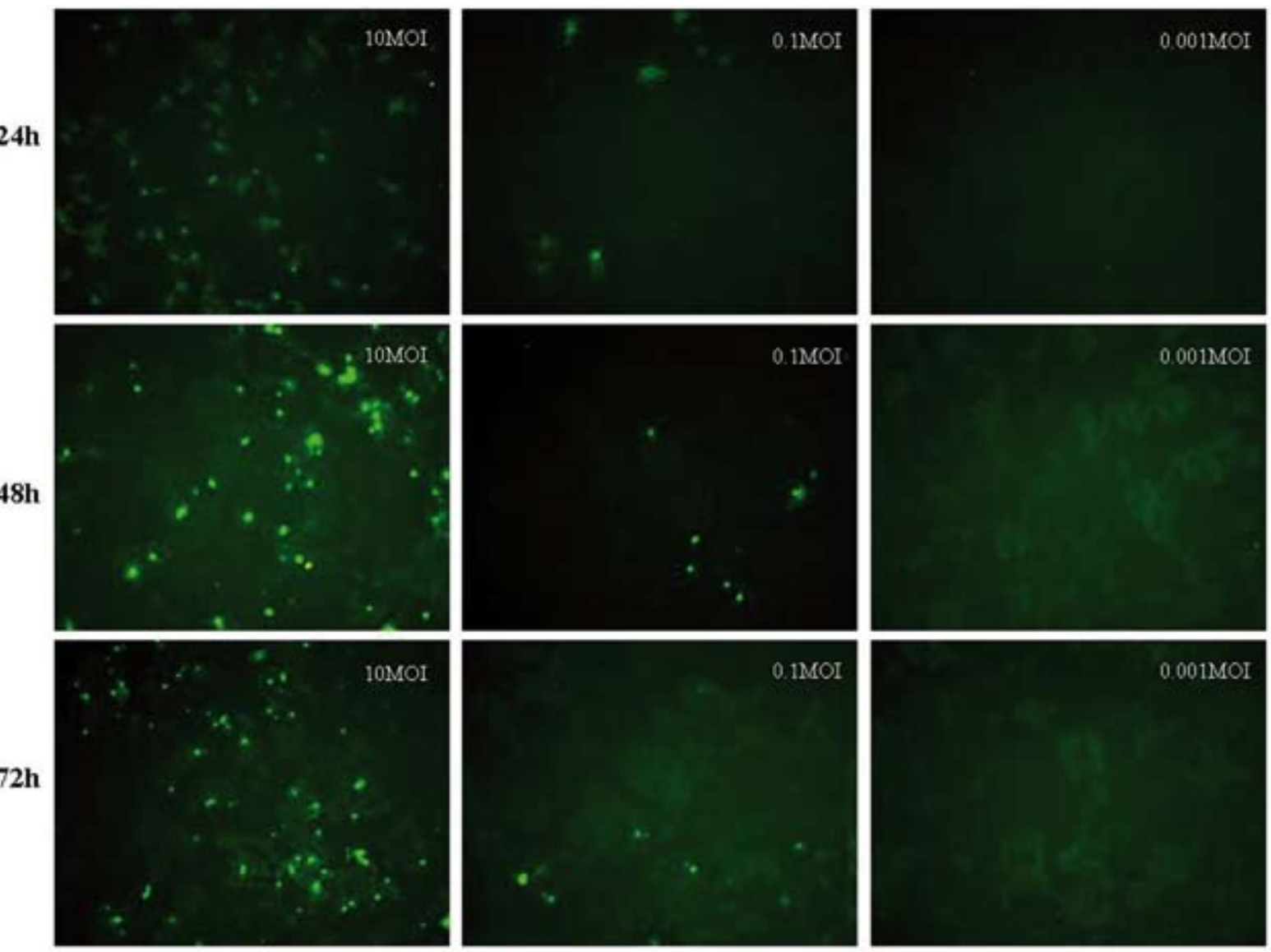

$0.001 \mathrm{MOI}$

Fig. 2c 
(d)

$48 \mathrm{~h}$
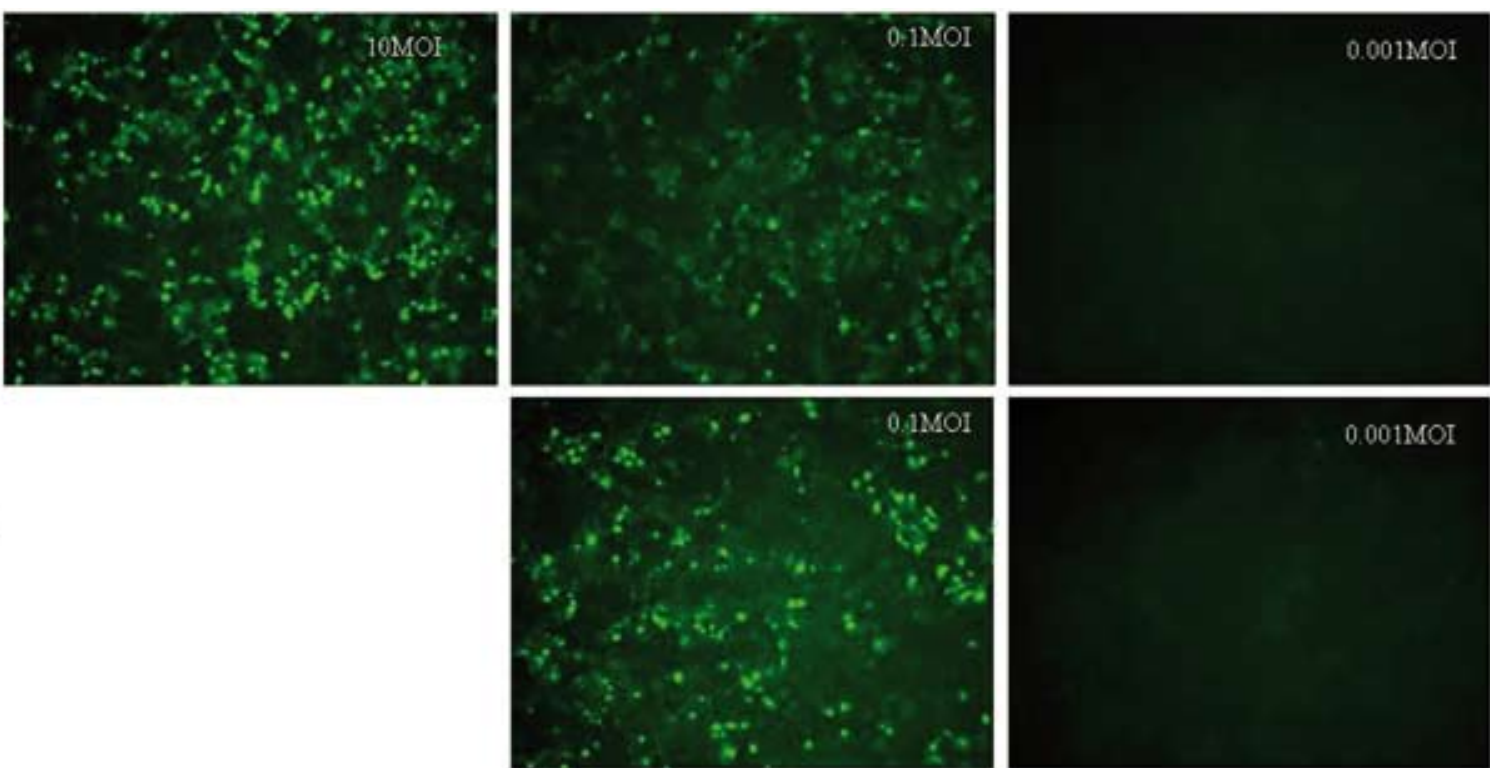

$0.001 \mathrm{MOI}$

$72 \mathrm{~h}$

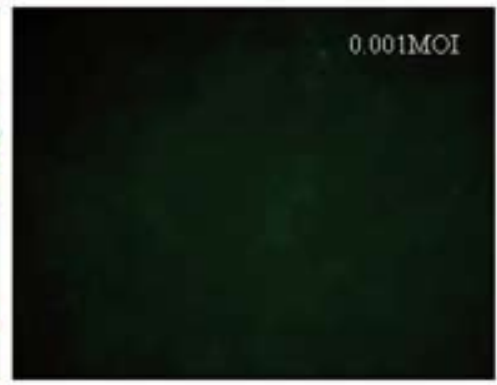

(e)
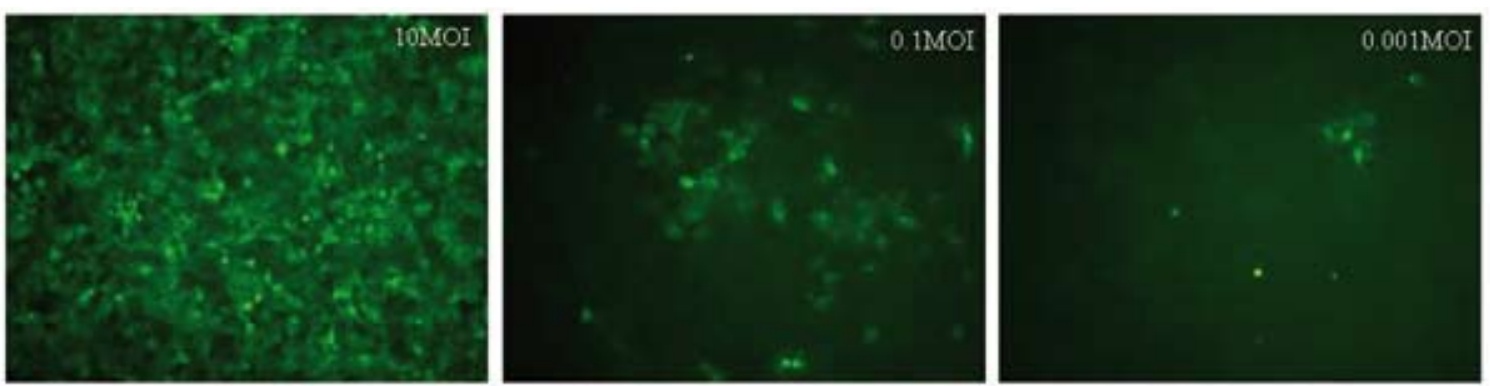

$10 \mathrm{MOI}$

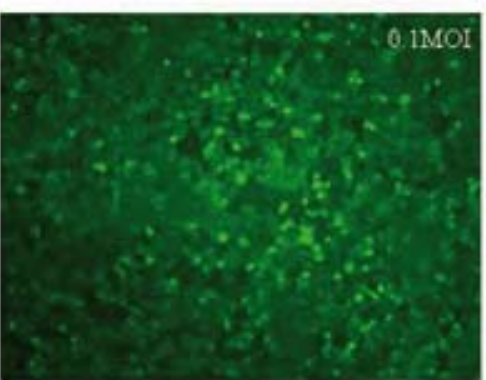

$0.001 \mathrm{MOI}$

$48 \mathrm{~h}$

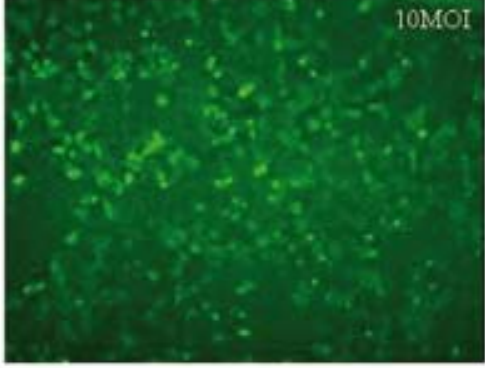

Negative Control
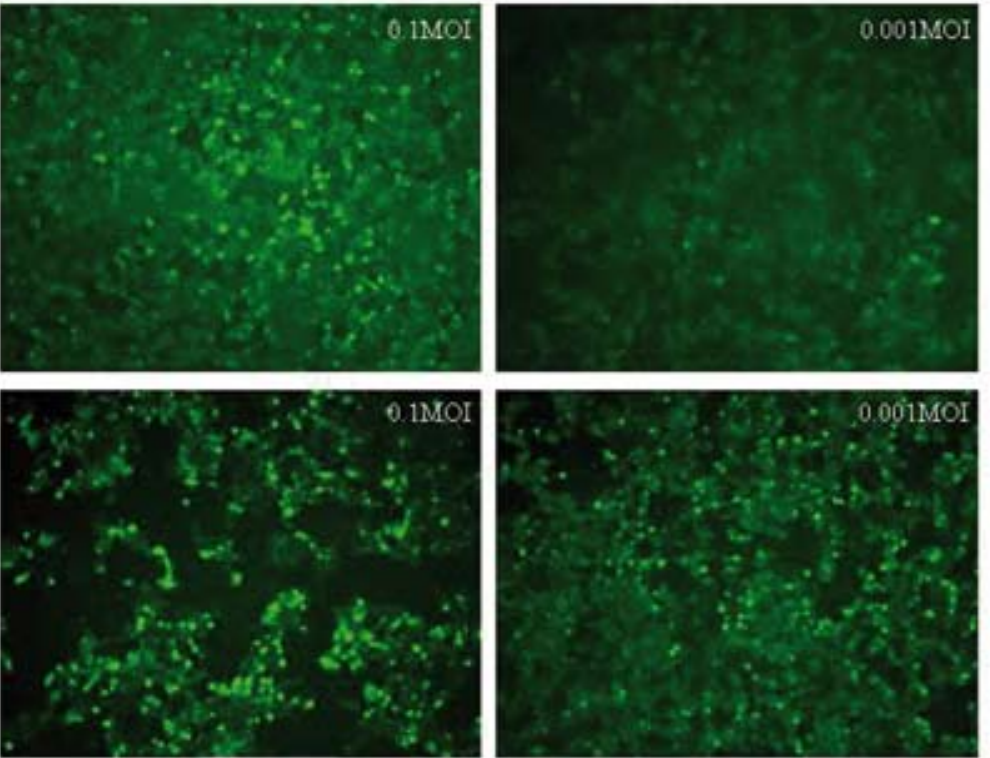

$72 \mathrm{~h}$

Fig. 2d, e

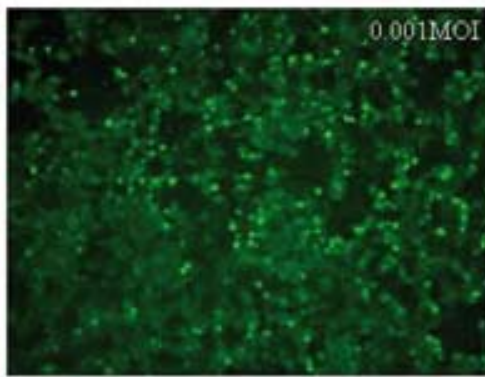


(f)

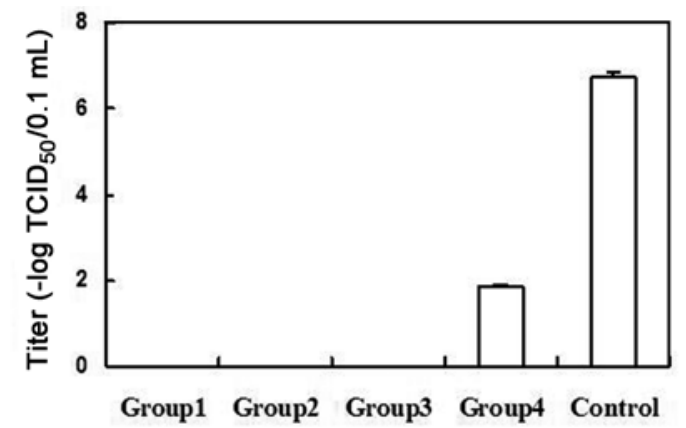

Fig. 2

Recombinant IFN- $\beta$ could clear the low-dose infection with PRRSV MARC-145 cells were divided into five groups [Group 1 (a), Group 2 (b), Group 3 (c), Group 4 (d) and Control (e)] and treated as the design of Figure.1 (see details in Fig. 1) then the cells were analyzed by immunofluorescence $(100 \times)$ at $24 \mathrm{hr}, 48 \mathrm{hr}$ and $72 \mathrm{hr}$ p.i., respectively. The negative control, which was mock-infected with PRRSV, is also shown in e. (f) the virus titers which were measured by $50 \%$ tissue culture infected dose $\left(\mathrm{TCID}_{50}\right)$ using the Reed-Muench method. MOI: multiplicity of infection.

PRRSV nucleocapsid $(\mathrm{N})$ protein is a major structural component essential for viral assembly, so its expression was a prerequisite for viral assembly and survival. Next, we did the indirect-immunofluorescence of $\mathrm{N}$ protein and found that there were a few $\mathrm{N}$ protein-positive cells in Group 1 (Fig. 2a, MOI = 10), Group 2 (Fig. 2b, MOI = 10) and Group 3 (Fig. 2c, MOI $=10$ and 0.1 ), but the number of $\mathrm{N}$ protein-positive cells in Group 1, Group 2 and Group 3 didn't increase in the following days (Fig. 4) and the number was much lower than that in Group 4 (Fig. 2d, MOI = 10 and 0.1) and in Control (Fig. 2e, MOI $=10$ and 0.1$)$. The treatment with $\mathrm{rIFN}-\beta(1000 \mathrm{unit} / \mathrm{ml})$ did not influence the cell viability of MARC-145 cells (Fig. 3).

As shown in Fig. 4, the number of N protein-positive cells in high-dose infected cells (MOI = 10) in Group 1 was lower than that in Group 2, while the number of N protein-positive cells in high-dose infected cells $(\mathrm{MOI}=10)$ in Group 2 was lower than that in Group 3.

Both pre-treatment and post-treatment with rIFN- $\beta$ could clear the low-dose infected PRRSV

Fig. 2 shows that there were no N protein-positive cells in cultures infected with 0.001 MOI of PRRSV in Group 1, Group 2, Group 3 and Group 4, but in contrast, the control cells infected with $0.001 \mathrm{MOI}$ of PRRSV not only had many $\mathrm{N}$ protein-positive cells, but finally developed CPE.

\section{Discussion}

It has been extensively documented that CPE induced by PRRSV infection in MARC-145 cells only appeared after 72

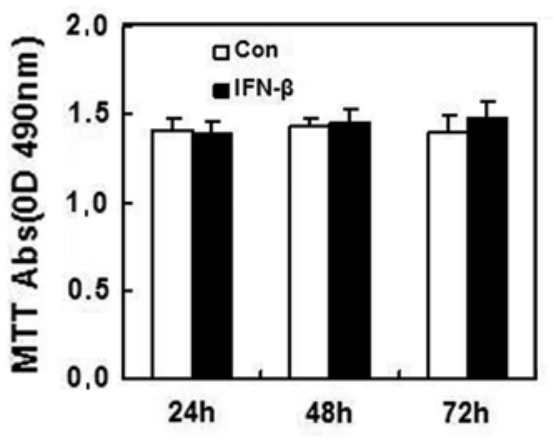

Fig. 3

Effect of rIFN- $\beta$ on MARC-145 cell viability after $24 \mathrm{hr}, 48 \mathrm{hr}, 72 \mathrm{hr}$ of rIFN- $\beta$ incubation

The cell viability was assessed by MTT method.

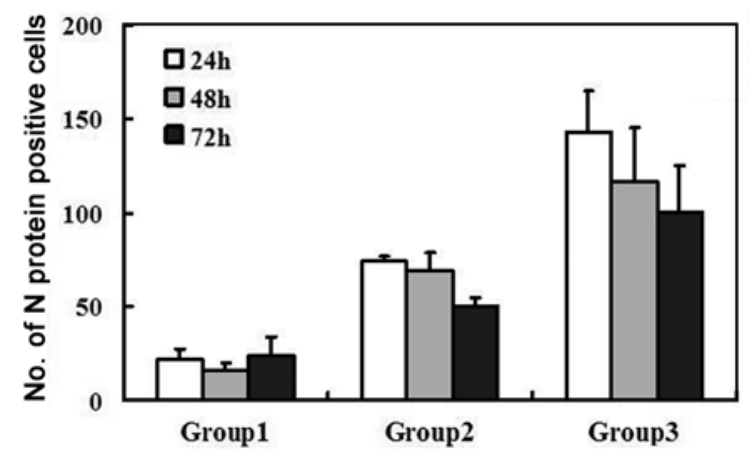

Fig. 4

The numbers of $\mathrm{N}$ protein-positive cells in cells infected with PRRSV at an MOI of 10 in Group 1, Group 2 and Group 3 didn't increase in the following days

The cells in five random fields were analyzed by fluorescence microscopy $(50 \times)$ and only one of them is shown.

hr p.i. (Cafruny et al., 2006), which has also been confirmed in our experiments. Overend et al. (2007) showed that pretreatment with the recombinant swine IFN- $\beta$ could reduce the viral loads in MARC-145 cells. Since the MARC-145 is a green monkey fetal fibroblast cell line derived from MA-104 (Kim et al., 1993), it may be more reasonable to use human recombinant IFN- $\beta$ than the swine recombinant IFN- $\beta$.

Besides the study from Albina et al. (1998), previous in vitro studies explored the inhibitory effect of pre-treatment with recombinant IFN- $\alpha$ on the replication of one-certain-dose PRRSV (Buddaert et al., 1998; Dong et al., 2012). The study of Albina et al. (1998) only showed that after pretreatment with higher-dose recombinant IFN- $\alpha$ a higher-dose PRRSV was needed to infect the macrophages and the study didn't show the following dynamic results (e.g. changes of PRRSV loads). The previous in vitro studies of rIFN- $\beta$ (Overend 
et al., 2007), recombinant type II interferon (Bautista and Molitor, 1999; Rowland et al., 2001) or recombinant type III interferon (Luo et al., 2011) also only explored the inhibitory effect on the replication of one-certain-dose PRRSV. In our present study, it was the first time that the effect of pre- and post-infection-treatment of MARC-145 with rIFN- $\beta$ on the replication of PRRSV following infection with different doses of PRRSV was explored.

Our present study showed that the rIFN- $\beta$ could inhibit PRRSV replication in MARC-145 cells infected with high dose of PRRSV, which was consistent with previous studies (Overend et al., 2007; Luo et al., 2011). However, there were two novel results obtained in our present work: (i) treatment with rIFN- $\beta$ could clear PRRSV after low-dose infection; (ii) post-treatment with rIFN- $\beta$ at earlier times of p.i. ( $4 \mathrm{hr}$ or $8 \mathrm{hr}$ p.i.) could also control the high-dose infection with PRRSV, while treatment with rIFN- $\beta$ at later post-infection ( $24 \mathrm{hr}$ p.i.) could not. This indicated that there may be a balance in the war between the host cell and the virus, that is, if the infection dose was high and the infection time was long, it would be advantageous for the virus survival and assembly; inversely, if the host cell established the defensive system induced by IFN- $\beta$, then it would be useful for the host to clear or control the virus. Thus, treatment with rIFN- $\beta$ in time and the methods for control of the viral loads of PRRSV may be the useful combination therapy for treating and clearing PRRSV in an in vivo study in future. Treatment with rIFN- $\beta$ before infection or at earlier times of p.i. could control the high-dose infection with PRRSV, and the number of $\mathrm{N}$ protein-positive cells didn't increase in the following days, which indicated that the rIFN- $\beta$ may inhibit the assembly and survival of the viruses. However, this needs further study.

Previous studies have shown that PRRSV could express proteins that inhibit the production and the function of IFN- $\beta$ (Chen et al., 2010; Shi et al., 2010, 2011a,b, 2013; Wang et al., 2013), while our present study found that pretreatment with rIFN- $\beta$ could control the PRRSV better than post-treatment with $\operatorname{rIFN}-\beta$, which indicated that the production time of IFN- $\beta$ took an important role for the efficiency of IFN- $\beta$ to inhibit or control PRRSV. The present work also found that both pre-treatment and post-treatment with rIFN- $\beta$ could clear low-dose infection by PRRSV, which indicated that the viral load may have an effect on the ability of IFN- $\beta$ to inhibit or control PRRSV. Thus, a balance model between PRRSV and IFN- $\beta$ could be proposed: first, once the cells could produce IFN- $\beta$ in time and then the cells express one or more antiviral proteins or other antiviral components, it would be difficult for PRRSV to replicate in the cells even if the cells were faced with the high-dose PRRSV; Second, if the PRRSV expressed the IFN antagonists in time, adding rIFN- $\beta$ would not prevent the replication of PRRSV. It may be an important and interesting work for prevention and treatment of PRRSV in future to determine, which genes or other components induced by IFN- $\beta$ have such important function to control and clear PRRSV.

Acknowledgements. This work was supported by the National Natural Science Foundation of China (grant No. 31302073), a 973 Program (No.2014CB542700), the key project of National Natural Science Fund (No.31490600), National Foundation of China (grant No. 31472177), the Doctoral Starting up Foundation of Henan Normal University (qd14158), the key scientific research projects of Henan provincial institution of higher education (16A180008) and Natural Science Foundation Project of CQ CSTC (cstc2012jjA10108).

\section{References}

Albina E, Carrat C, Charley B (1998): Interferon-alpha response to swine arterivirus (PoAV), the porcine reproductive and respiratory syndrome virus. J. Interferon Cytokine Res. 18, 485-490. http://dx.doi.org/10.1089/jir.1998.18.485

Bautista EM, Molitor TW (1999): IFN gamma inhibits porcine reproductive and respiratory syndrome virus replication in macrophages. Arch. Virol. 144, 1191-1200. http://dx.doi. org $/ 10.1007 / \mathrm{s} 007050050578$

Bowie AG, Unterholzner L (2008): Viral evasion and subversion of pattern-recognition receptor signalling. Nat. Rev. Immunol. 8, 911-922. http://dx.doi.org/10.1038/nri2436

Buddaert W, Van Reeth K and Pensaert M (1998): In vivo and in vitro interferon (IFN) studies with the porcine reproductive and respiratory syndrome virus (PRRSV). Adv. Exp. Med. Biol. 440, 461-467. http://dx.doi.org/10.1007/9781-4615-5331-1 59

Cafruny WA, Duman RG, Wong GH, Said S, Ward-Demo P, Rowland RR, Nelson EA (2006): Porcine reproductive and respiratory syndrome virus (PRRSV) infection spreads by cell-to-cell transfer in cultured MARC-145 cells, is dependent on an intact cytoskeleton, and is suppressed by drug-targeting of cell permissiveness to virus infection. Virol. J. 3, 90. http://dx.doi.org/10.1186/1743-422$\underline{\mathrm{X}-3-90}$

Chen Z, Lawson S, Sun Z, Zhou X, Guan X, Christopher-Hennings J, Nelson EA, Fang Y (2010): Identification of two autocleavage products of nonstructural protein 1 (nsp1) in porcine reproductive and respiratory syndrome virus infected cells: nsp1 function as interferon antagonist. Virology 398, 87-97. http://dx.doi.org/10.1016/j. virol.2009.11.033

Dong S, Yin Y, Shen S, Guo Y, Gao M, Zhang W, Zhu Y, Yu R, Shi Z, Li Z (2012): Inhibitory effects of recombinant porcine interferon-alpha on high- and low-virulence porcine reproductive and respiratory syndrome viruses. Res. Vet. Sci. 93, 1060-1065. http://dx.doi.org/10.1016/j. $\underline{\text { rvsc. } 2011.12 .006}$

Kim HS, Kwang J, Yoon IJ, Joo HS, Frey ML (1993): Enhanced replication of porcine reproductive and respiratory syndrome (PRRS) virus in a homogeneous subpopulation of 
MA-104 cell line. Arch. Virol. 133, 477-483. http://dx.doi. org/10.1007/BF01313785

Le Bon A, Tough DF (2002): Links between innate and adaptive immunity via type I interferon. Curr. Opin. Immunol. 14, 432-436. http://dx.doi.org/10.1016/S0952-7915(02)00354-0

Luo R, Fang L, Jin H, Jiang Y, Wang D, Chen H, Xiao S (2011): Antiviral activity of type I and type III interferons against porcine reproductive and respiratory syndrome virus (PRRSV). Antiviral Res. 91, 99-101. http://dx.doi. org/10.1016/j.antiviral.2011.04.017

Mateu E, Diaz I (2008): The challenge of PRRS immunology. Vet. J. 177, 345-351. http://dx.doi.org/10.1016/j.tvjl.2007.05.022

Meulenberg JJ (2000): PRRSV, the virus. Vet. Res. 31, 11-21. http:// dx.doi.org/10.1051/vetres:2000103

Overend C, Mitchell R, He D, Rompato G, Grubman MJ, Garmendia AE (2007): Recombinant swine beta interferon protects swine alveolar macrophages and MARC- 145 cells from infection with Porcine reproductive and respiratory syndrome virus. J. Gen. Virol. 88, 925-931. http://dx.doi. org/10.1099/vir.0.82585-0

Rossow KD (1998): Porcine reproductive and respiratory syndrome. Vet. Pathol. 35, 1-20. http://dx.doi.org/10.1177/ $\underline{030098589803500101}$

Rowland RR, Robinson B, Stefanick J, Kim TS, Guanghua L, Lawson SR, Benfield DA (2001): Inhibition of porcine reproductive and respiratory syndrome virus by interferon-gamma and recovery of virus replication with 2-aminopurine. Arch. Virol. 146, 539-555. http://dx.doi.org/10.1007/ $\underline{\text { s007050170161 }}$

Sadler AJ, Williams BR (2008): Interferon-inducible antiviral effectors. Nat. Rev. Immunol . 8, 559-568. http://dx.doi. org/10.1038/nri2314
Shi X, Wang L, Li X, Zhang G, Guo J, Zhao D, Chai S, Deng R (2011a): Endoribonuclease activities of porcine reproductive and respiratory syndrome virus nsp11 was essential for nsp11 to inhibit IFN-beta induction. Mol. Immunol. 48, 1568-1572. http://dx.doi.org/10.1016/j. molimm.2011.03.004

Shi X, Wang L, Zhi Y, Xing G, Zhao D, Deng R, Zhang G (2010): Porcine reproductive and respiratory syndrome virus (PRRSV) could be sensed by professional beta interferonproducing system and had mechanisms to inhibit this action in MARC-145 cells. Virus Res. 153, 151-156. http:// dx.doi.org/10.1016/j.virusres.2010.07.028

Shi X, Zhang G, Wang L, Li X, Zhi Y, Wang F, Fan J, Deng R (2011b): The nonstructural protein 1 papain-like cysteine protease was necessary for porcine reproductive and respiratory syndrome virus nonstructural protein 1 to inhibit interferon-beta induction. DNA Cell. Biol. 30, 355-362. http://dx.doi.org/10.1089/dna.2010.1188

Shi X, Zhang X, Wang F, Wang L, Qiao S, Guo J, Luo C, Wan B, Deng R, Zhang G (2013): The zinc-finger domain was essential for porcine reproductive and respiratory syndrome virus nonstructural protein-1alpha to inhibit the production of interferon-beta. J. Interferon Cytokine Res. 33, 328-334. http://dx.doi.org/10.1089/ jir.2012.0100

Wang R, Nan Y, Yu Y, Zhang YJ (2013): Porcine reproductive and respiratory syndrome virus Nsp1beta inhibits interferonactivated JAK/STAT signal transduction by inducing karyopherin-alpha1 degradation. J. Virol. 87, 5219-5228. http://dx.doi.org/10.1128/JVI.02643-12

Weber F, Kochs G, Haller O (2004): Inverse interference: how viruses fight the interferon system. Viral Immunol. 17, 498-515. http://dx.doi.org/10.1089/vim.2004.17.498 